\title{
EGIPTO GYNYBOS MINISTRO 2013 M. LIEPOS 3 D. VEIKSMŲ KONSTITUCINIAI PAGRINDAI: LYGINAMOJI ANALIZE்
}

\author{
Kristina Kenstavičienè \\ Mykolo Romerio universiteto Teisès fakulteto \\ Konstitucinès ir administracinès teisès institutas \\ Ateities g. 20, LT-08303 Vilnius, Lietuva \\ Telefonas (+370 5) 2714546 \\ Elektroninis paštas k.kenstaviciene@mruni.eu
}

Pateikta 2013 m. rugpjūčio23 d., parengta spausdinti 2014 m. kovo 28 d.

doi:10.13165/SMS-14-6-1-07

Anotacija. Liberalios demokratinès valstybès kariauja, kad apsaugoty fundamentalia valdymo forma nuo užpuolimu, ar tai būtu valstybès, besivadovaujančios skirtingais konstituciniais principais, ar teroristines organizacijos, ketinančios sunaikinti jos integraluma ${ }^{1}$. Tačiau visuomeniniai neramumai pačios valstybès viduje ir galiausiai 2013 m. liepos 3 d. Egipto gynybos ministro veiksmai iškèle klausima, o kokios priemonès užtikrina demokratinę kariuomenès kontrolę, ar demokratine valstybé gali apriboti ir kontroliuoti ginkluotuju pajegu panaudojima demokratiškai. Valstybès vadžios instituciju galiu pasiskirstymas (valdžiu padalijimo principas) pirmiausiai įtvirtinamas konstitucijoje. Šiame straipsnyje, lyginant su kitu valstybių, įkūnijančių skirtingas valdymo formas, konstitucinemis nuostatomis, analizuojamas $2012 \mathrm{~m}$. gruodžio 26 d. Egipto Arabu Respublikos Konstitucijoje įtvirtintas valstybès vadovo, kaip vyriausiojo ginkluotuju pajegu vado, konstitucinis statusas ir kokie konstituciniai pagrindai egzistavo Egipto gynybos ministro $2013 \mathrm{~m}$. liepos $3 \mathrm{~d}$. veiksmams atlikti arba užkirsti kelia jiems atlikti.

1 Yasuo, H. War Powers. The Oxford handbook of comparative constitutional law. Oxford: Oxford University Press, 2012, p. 464.

Socialinių mokslų studijos / Societal Studies

(C) Mykolo Romerio universitetas, 2014

(C) Mykolas Romeris University, 2014
ISSN 2029-2236 (print), ISSN 2029-2244 (online) http://www.mruni.eu/lt/mokslo_darbai/SMS/ http://www.mruni.eu/en/mokslo_darbai/SMS/ 
Reikšminiai žodžiai: valstybès vadovas, kaip vyriausiasis ginkluotujų pajegu vadas, gynybos ministras, kariuomenès vadas, Konstitucija.

\section{Ivadas}

Prisiminkime $2013 \mathrm{~m}$. liepos $3 \mathrm{~d}$. visuomenès informavimo priemonèse ${ }^{2}$ pasklidusią žinią, kad Egipto armija suèmė ir pašalino iš pareigų valstybès Prezidentą Mohamedą Mursị, kuris atsisakè vykdyti karinị 48 val. ultimatumą - atsistatydinti iš pareigų dèl šalyje kilusios politinès krizès. Valstybės valdžia buvo sutelkta islamiškų jègų (Musulmonų brolijos) rankose, vis ryškèjo ekonomikos smukimas, o tai vis labiau stiprino Respublikos Prezidento oponentų nepasitenkinimą ${ }^{3}$. Egipto opozicijos lyderis Hamdeenas Sabbahi paragino kariškius ịsikišti po keturias dienas trukusių protestų, kurių dalyviai reikalavo Prezidento atsistatydinimo. Negana to, iš karto po kariškių sprendimo nušalinti nuo valdžios Prezidentą Egipto ginkluotųjų pajègų vadas, kuris taip pat yra gynybos ministras, pareiške் $\dot{4}^{4}$ kad sustabdo 2012 m. gruodžio 26 d. Egipto Arabų Respublikos Konstitucijos galiojimą, paleidžia parlamentą, o Konstitucinio Teismo vyriausiasis teisejjas perims prezidento galias. Šis pareiškimas reiškè, kad Prezidentas Mohamedas Mursi, kuris buvo pirmasis demokratiškai išrinktas tautos, nebeteko valdžios. Praejjus mažiau nei pusei paros po to, kai kariškiai nuvertè valstybės vadovą, Aukščiausiajame Konstituciniame Teisme teisejjas Adly Mansouras duodamas priesaiką per ceremoniją sakė: „Prisiekiu išlaikyti respublikos santvarką, gerbti konstituciją ${ }^{5}$ ir ịstatymus bei ginti žmonių interesus“. Kad šalyje prasidejo balansavimas tarp demokratinio bei nedemokratinio režimo, patvirtina ir tai, jog Egipto nacionalinejje spaudoje akcentuota „tautos revoliucija“, „revoliucijos

2 Žr. Perversmas Egipte: kariuomenė perima valdymą [interaktyvus]. 2013 m. liepos 3 d. [žiūrèta 2013-07-03]. <http://www.delfi.lt/news/daily/world/perversmas-egipte-kariuomene-perima-valdy ma.d?id=61771469>.

3 Be to, Egipto armija „prevenciškai“ laiko nušalintąji šalies prezidentą, nes prokurorai gali pateikti kaltinimus M. Mursiui dèl jo ir kitų kalinių pabėgimo iš kalẻjimo per sukilimą 2011 metais, kurio metu buvo nuverstas jo pirmtakas Hosni Mubarakas. Žr. Nušalintas Egipto prezidentas M. Mursi pateko ị kariškių rankas [interaktyvus]. $2013 \mathrm{~m}$. liepos 4 d. [žiūrèta 2013-07-04]. <http://www.delfi.lt/news/daily/world/nusalintas-egipto-prezidentas-m-mursipateko-i-kariskiu-rankas.d?id=61772681\#ixzz2cDjF2knC>.

4 Statement from the General Command of Egypt's Armed Forces [interaktyvus]. 3rd July 2013 [žiūrèta 2013-07-10]. <http://soupsoup.net/2013/07/04/statement-from-the-general-commandof-egypts-armed-forces/>.

$5 \quad$ Reikia paskyti, kad nuo to laiko, kai $2013 \mathrm{~m}$. liepos 3 d. gynybos ministras paskelbė bendrą ginkluotųjų pajègų pareiškimą, jog sustabdomas $2012 \mathrm{~m}$. gruodžio $26 \mathrm{~d}$. Konstitucijos galiojimas iki tol, kol laikinasis Egipto Prezidentas prième $2013 \mathrm{~m}$. liepos $8 \mathrm{~d}$. konstitucinę deklaraciją, šalyje nebuvo galiojančios konstitucijos. Žr.: The Constitutional Declaration on 8 July 2013 [interaktyvus]. 8 July 2013 [žiūrèta 2013-07-10]. <http://www.constitutionnet.org/vl/item/ egypt-constitutional-declaration-8-july-2013>. 
legitimumas“ ir taip siekta suteikti karinių pajègų veiksmams teisètumą bei išsklaidyti abejones, ar ịvykiai nèra apibūdintini kaip perversmas ${ }^{6}$.

Šiame kontekste galima suprasti Jungtinių Amerikos Valstiju (toliau - JAV) Prezidento nacionalinio saugumo komandos, NATO generalinio sekretoriaus, Vokietijos užsienio reikalų ministro ar Jungtinių Tautų generalinio sekretoriaus raginimus Egiptą kuo greičiau grị̌zi prie konstitucinès santvarkos bei prie civilinès vyriausybès, kuri atspindètų egiptiečių, t. y. visos tautos, valią.

Egipto i̇vykiai verčia susimąstyti, ar iš tiesų demokratineje valstybèje teisèti minèti ginkluotųjų pajègų veiksmai ir, visų pirma, kariuomenès vado, gynybos ministro, bei kokios demokratinès priemonės užtikrina jų kontrolę. Aktualu, ar tokių valstybių kaip JAV, Jungtinė Karalystė, Vokietija bei Prancūzija demokratija, kuri $\mathrm{XX}$ a. yra tapusi pavyzdžiu daugeliui naujai susikūrusių ar nepriklausomybę atgavusių valstybių, inter alia Lietuvai, taip pat yra pavojuje. Todèl šio straipsnio tikslas - išanalizuoti gynybos ministro ir valstybès vadovo, kaip vyriausiojo ginkluotųju pajègų vado, konstitucinę padètị valstybès valdžios institucijų sistemoje, atsakant $\mathfrak{i}$ klausimą, ar gynybos ministrui suteikta teisè pašalinti valstybès vadovą, kaip vyriausiąji ginkluotụjų pajègų vadą, iš pareigų, o konstitucinès justicijos institucijos teiseją paskirti laikinai eiti prezidento pareigas. Straipsnyje remiamasi ne tik Egipto, bet ir JAV, Jungtinès Karalystès, Vokietijos, Prancūzijos konstitucinių nuostatų analize, o jos pagrindu atliekamas ir Lietuvos Konstitucijos atitinkamų straipsnių vertinimas.

Rašant straipsnị remtasi prof. E. Jarašiūno ${ }^{7}$, prof. M. Vainiutès ${ }^{8}$, prof. D. Žalimo ${ }^{9}$ ir kt. autorių moksliniais darbais, kuriuose nagrinejjamas valstybès vadovo konstitucinis statusas, taip pat Lietuvos Respublikos Konstitucinio Teismo jurisprudencija ${ }^{10}$, kurioje pateikiami valstybès gynybos konstituciniai pagrindai.

6 Egipto spauda giria prezidento M. Mursi atstatydinimą [interaktyvus]. $2013 \mathrm{~m}$. liepos 4 d. [žiūrèta 2013-07-04]. <http://www.delfi.lt/news/daily/world/m-mursi-nuo-kalejimo-iki-egipto-prezidenturos-ir.d?id=61777107>.

7 Jarašiūnas, E. Prancūzijos Respublikos Prezidento konstitucinis statusas. Prezidentas valstybinés valdžios instituciju sistemoje. Vilnius: MES, 2011.

8 Vainiute, M. Vokietijos Federacinès Respublikos Prezidento konstitucinis statusas. Prezidentas valstybinès valdžios instituciju sistemoje. Vilnius: MES, 2011.

9 Žalimas, D. Lietuvos Respublikos užsienio politikos konstituciniai pagrindai. Lietuvos konstitucine teisé: vadovèlis: liber amicorum Juozui Žiliui. Vilnius: Mykolo Romerio universitetas, 2012.

10 Lietuvos Respublikos Konstitucinio Teismo 2011 m. kovo 15 d. nutarimas „Dèl tarptautinių karinių operacijų, pratybų ir kitų karinio bendradarbiavimo renginių“. Valstybès žinios. 2011, Nr. 32-1503; Lietuvos Respublikos Konstitucinio Teismo 2004 m. gruodžio 13 d. nutarimas „Dèl valstybès tarnybos“. Valstybės žinios. 2004, Nr. 181- 6708; Atitaisymas: 2004, Nr. 186; Lietuvos Respublikos Konstitucinio Teismo 2002 m. gruodžio 24 d. nutarimas „Dèl savivaldos atstovaujamųjų ir vykdomųjų institucijų kompetencijos“. Valstybės žinios. 2003, Nr. 19-828; Lietuvos Respublikos Konstitucinio Teismo 1996 m. gegužès 29 d. sprendimas „Dèl pradètos teisenos nutraukimo“. Valstybès žinios. 1996, Nr. 57-1364. 
Mokslinis tyrimas atliktas taikant mokslinès literatūros bei teisès aktų analizès, sisteminimo, vertinimo ir apibendrinimo teorinius metodus .

\section{Respublikos Prezidento konstituciniai igaliojimai vadovauti Vyriausybei, kurios nariu yra gynybos ministras}

Prieš bandant atsakyti ị klausimą, kas - valstybès vadovas ar gynybos ministras yra vyriausiasis ginkluotųjų pajègų vadas, lyginant su kitų valstybių konstitucinėmis nuostatomis, aptarsime, koks Egipto Respublikos Prezidento konstitucinis statusas valstybès valdžios institucijų sistemoje, kokie Respublikos Prezidento konstituciniai igaliojimai vadovuti Vyriausybei, inter alia gynybos ministrui. Egipte $2013 \mathrm{~m}$. liepos 3 d. galiojo 2012 m. gruodžio 26 d. Egipto Arabų Respublikos Konstitucija ${ }^{11}$, todèl ja ir remsimès tolesnèje analizèje.

Iš pirmo žvilgsnio Egipto Konstitucija ${ }^{12}$ atrodo gana demokratiška: pirmos dalies straipsniai ịtvirtina valstybès politinès santvarkos principus, socialinius, etinius, ekonominius principus; antra dalis - žmogaus teises bei laisves; trečiosios dalies nuostatos reglamentuoja valstybès valdžios institucijų sistemą bei statusą, o ketvirtosios dalies - nepriklausomas institucijas ir reguliavimo agentūras; galiausiai, penktoje dalyje numatytos baigiamosios ir pereinamosios nuostatos, aptariami tokie klausimai, kaip Konstitucijos keitimas, valstybès sostinè, vèliava ir pan.

Tačiau 2013 m. liepos 3 d. ịvykiai Egipte, kai kariuomenès vadas èmèsi veiksmų prieš kitas valstybės valdžios institucijas, vis dèlto kelia abejonių, ar nagrinèjama Konstitucija nèra tik demokratiškumo fasadas, deklaruojantis konstitucines vertybes, kurios paneigiamos valstybės valdžios institucijų praktika? Juo labiau kad pagal Konstituciją gynybos ministras nèra Konstitucijos garantas (saugotojas), be to, jam nenumatyta teisè sustabdyti Konstitucijos galiojimą. Kitaip tariant, susiduriame su konstitucijos fiktyvumo klausimu ${ }^{13}$.

Vis dèlto tai, kad Egipte ginkluotosioms pajėgoms suteikta ypatinga reikšmė, patvirtina jau Konstitucijos preambulè, kuri skelbia:

11 Po $2011 \mathrm{~m}$. sausio 25 d. Egipte kilusios revoliucijos (dar viena iš Arabų pavasario, prasidejusio 2010 m. gruodžio 18 d., revoliucijų), raginusios nuversti esamą režimą, 2012 m. birželio $24 \mathrm{~d}$. demokratiniuose, visuotiniuose rinkimuose surinkus 51,73 proc. balsų buvo išrinktas pirmasis Egipto Arabų Respublikos Prezidentas, kuris 2012 m. birželio 30 d. davė konstitucinę priesaiką Aukščiausiajame Konstituciniame Teisme. 2012 m. gruodžio 26 d. Prezidentas pasirašè naują Egipto Arabų Respublikos Konstituciją po to, kai ji buvo patvirtinta Steigiamojo susirinkimo $2012 \mathrm{~m}$. lapkričio $30 \mathrm{~d}$. ir referendume $2012 \mathrm{~m}$. gruodžio 15-22 d.

12 The Constitution of the Arab Republic of Egypt - approved on 30 Nov 2012 [interaktyvus]. 30 November 2012 [žiūrèta 2013-07-10]. <http://www.constitutionnet.org/vl/item/new-constitution-arab-republic-egypt-approved-30-nov-2012>.

13 Tačiau atsižvelgiant ị užsibrèžtą šio mokslinio tyrimo tikslą, straipsnyje nebus siekiama minètą teiginị patvirtinti ar paneigti. 
„Mes, Egipto žmonès,

gailestingiausiojo ir maloningiausiojo Dievo vardu ir su jo pagalba,

skelbiame, kad tai yra mūsu Konstitucija... Sausio 25 d revoliucijos dokumentas, revoliucijos, kuria inicijavo mūsu jaunimas, kuri sutelkè mūsų žmones ir kuria palaikè ginkluotosios pajegos. <...>

Tęsiant mūsu nepriekaištingos revoliucijos, kuri suvienijo Egipto žmones dèl vieno tikslo - sukurti šiuolaikišką demokratinę valstybę, mes skelbiame nustatantys šiuos principus: $<$...>

Aštuntas: ginti tèvyne yra pareiga ir garbè, o mūsu ginkluotosios pajégos yra patriotine, profesionali ir neutrali institucija, kuri nesikiša į politinius reikalus ir yra šalies apsauginis skydas."

Egipto Konstitucijos 5 straipsnyje numatyta, kad suverenitetas priklauso žmonèms, kurie ji tigyvendina ir gina bei saugo nacionalinę vienybę. Žmonès yra valdžios šaltinis, tačiau pasigendama detalumo, kaip suverenitetas igyvendinamas ir kokios institucijos ịgyvendina valstybės valdžią. Daugelio demokratinių valstybių konstitucijose eksplicitiškai nurodoma, kad suverenitetas igyvendinamas tiesiogiai arba per demokratiškai išrinktus tautos atstovus. Todèl tenka analizuoti Konstitucijos formą bei straipsnių išdèstymą pagal tam tikrus institutus.

Kaip minèta, Egipto Konstitucijos trečioji dalis, reglamentuojanti valstybės valdžios institucijų sistemą bei statusą, pirmiausiai pradedama nuo ịstatymų leidžiamosios valdžios, kuri suteikta dvejų rūmų parlamentui (Atstovų taryba - žemieji parlamento rūmai, Shura taryba - aukštieji parlamento rūmai). Antrasis skyrius skirtas vykdomajai valdžiai, kuriai priklauso Respublikos Prezidentas ir Vyriausybė.

Egipto Prezidentas yra valstybès vadovas ir kartu vykdomosios valdžios vadovas (132 str.). Tokia konstitucinè nuostata tarsi sudarytų pirminę prielaidą teigti, jog tai vienas iš prezidentinio valdymo bruožų ${ }^{14}$, tačiau tolesnè analizè tai paneigia. Egipto Konstitucijoje numatyta, kad valstybès vadovas prezidentinius igaliojimus igyvendina per Ministrą Pirmininką ${ }^{15}$, jo pavaduotojus ir ministrus, o tai jau panašu i Jungtinès Karalystės monarcho konstitucinę padėtị. Nors Jungtinès Karalystės monarchas kaip suverenas valstybès valdžios institucijų sistemoje užima pirmą vietą ir kartu formaliai yra vykdomosios valdžios vadovas, de facto Vyriausybe veikia monarcho vardu ir igyvendina Karūnos prerogatyvas ${ }^{16}$. Tuo tarpu Egipto Konstitucijoje nerasi-

14 Jungtinių Amerikos Valstijų Konstitucijos 1787 m. II straipsnio 1 skyrius taip pat skelbia, kad vykdomoji valdžia priklauso Jungtinių Amerikos Valstijų Prezidentui, kuris vienasmeniškai už jos vykdymą atsakingas Kongresui.

15 Formuojant Vyriausybę Egipte, panašiai kaip ir kitose valstybėse, Respublikos Prezidentas paskiria asmenị Ministru Pirmininku bei paveda jam suformuoti Vyriausybę (139 str.), kurių narius Ministras Pirmininkas skiria be derinimo su Prezidentu. Tačiau suformuota Vyriausybė turi pristatyti savo veiklos programą Atstovų taryboje ir gauti žemụjų parlamento rūmų pasitikejjimą. Vyriausybės bei gynybos ministro atskaitomybė Prezidentui nenumatyta.

16 Išskyrus Karūnos asmenines prerogatyvas, taip pat kai kurias svarbiausias politines prerogatyvas, kaip, pavyzdžiui, parlamento paleidimo teisè, Ministro Pirmininko paskyrimas, žr. Bar- 
me nuorodos, kad Ministras Pirmininkas, jo pavaduotojai ar ministrai prezidentinius igaliojimus igyvendina valstybès vadovo vardu. Todèl trūksta aiškumo, kieno vardu tokie igaliojimai igyvendinami ir kam už jų igyvendinimą kyla atsakomybė.

Galima paminèti, jog Vokietijos Federaliniam Prezidentui yra nustatyta konstitucinè pareiga nepriklausyti nei vykdomajai, nei įstatymų leidžiamajai institucijai, t. y. Prezidentui suteikiami reprezentaciniai igaliojimai. Apibūdindama Vokietijos Federalinị Prezidentą, M. Vainiute $\dot{~}^{17}$ nurodo, jog jis yra „valstybès institucija, kuriai ypač būdingas neutralumas - jis politiškai nepriklausomas“. Beje, Egipto Konstitucija taip pat draudžia Prezidentui kadencijos laikotarpiu būti šališkam, nors ir nepateikia detalesnio tokio draudimo turinio, skirtingai nei Lietuvos Respublikos Konstitucija ${ }^{18}$. Galiausiai, kaip kontrastas aptartiems valstybių vadovams, paminètinas Prancūzijos Prezidento vaidmuo, kuris ypač išauga, jei jis yra faktinis parlamento daugumą sudarančių politinių jègų lyderis ${ }^{19}$. Pasak E. Jarašiūno, tokiu atveju Prancūzijos Prezidentas „stipresnis“ nei prezidentinés respublikos prezidentas. Dėl to politikos mokslų literatūroje apibūdinant Prancūzijos Penktosios Respublikos politinę sistemą kartais net vartojama „respublikinès monarchijos“ kategorija ${ }^{20}$.

Dar vienas Egipto Konstitucijos trūkumas - nèra Prezidento igaliojimų sąrašo, išskyrus išimtinius ${ }^{21}$, nustatytus 142 straipsnyje. Ir nors tam tikri konstituciniai tikslai keliami asmeniui, einančiam Egipto Prezidento pareigas, - ginti žmonių interesus, saugoti šalies nepriklausomybę ir teritorinị vientisumą, valdžių padalijimą

nett, H. Constitutional and administrative law. London: Cavendish Publishing Limited, 2004, p. 99, 130-131.

17 Vainiutè, M., supra note 8, p. 495.

18 Nors Lietuvoje, kaip ir Egipte, vykdomoji valdžia yra dualistinė, priskirta Respublikos Prezidentui ir Vyriausybei, tačiau pagal Konstitucijos 83 str. 2 d.: „Asmuo, išrinktas Respublikos Prezidentu, turi sustabdyti savo veiklą politinese partijose ir politinėse organizacijose iki naujos Respublikos Prezidento rinkimų kampanijos pradžios“, o duodamas priesaiką ịsipareigoja „būti visiems lygiai teisingas“ (82 str. 1 d.).

19 Pagal Prancūzijos Respublikos 1958 m. Konstitucijos 7 straipsnị Respublikos Prezidentas pirmininkauja Ministrų Tarybai, kuri yra pagrindinè Vyriausybès, atskaitingos tiek parlamentui, tiek Prezidentui, veiklos forma. Tokiuose posèdžiuose priimami teisès aktai pasirašomi Respublikos Prezidento ir tik ypatingais atvejais Respublikos Prezidentas gali perduoti Ministrui Pirmininkui teisę pirmininkauti Ministrų Tarybai.

20 Jarašiūnas, E., supra note 7, p. 445.

21 Konstitucinis imperatyvas draudžia Egipto Prezidentui per Ministrą Pirmininką, jo pavaduotojus ir ministrus, inter alia gynybos ministrą, igyvendinti igaliojimus, susijusius su gynyba, nacionaliniu saugumu ir užsienio politika bei nustatytus Konstitucijos 139 (vyriausybès formavimas), 145 (užsienio santykiai), 146 (vadovavimas ginkluotosioms pajègoms), 147 (civilių ir karinių tarnautojų skyrimas), 148 (nepaprastosios padètis paskelbimas) ir 149 (malonès ir amnestijos teisè) straipsniuose (141 str.). Kitaip tariant, šie igaliojimai išimtinai priskirti tik valstybès vadovui. Vis dèlto dalį savo iggaliojimų Respublikos Prezidentas gali pavesti Ministrui Pirmininkui, jo pavaduotojams, ministrams ar gubernatoriams, tačiau igyvendinimo tvarką nustato įstatymas (142 str.). Reikia pabrèžti, kad toks ịstatymas turètų paisyti prieš tai minèto konstitucinio imperatyvo. 
(132 str.), vis dèlto sunku vienareikšmiškai pasakyti, ką suponuoja konstitucinè nuostata „Prezidentas yra vykdomosios valdžios vadovas“. Ar jis tik formaliai (panašiai kaip ir Jungtinèje Karalystėje, kai monarcho igaliojimus vyriausybė igyvendina jo vardu), ar realiai (kaip Prancūzijoje Prezidentas, kai vadovauja Ministrų Tarybos posédžiams) yra vykdomosios valdžios vadovas, todèl gali duoti privalomus nurodymus ministrams, inter alia gynybos ministrui?

Egipto Konstitucijos 158 straipsnio, ịtvirtinančio pagrindines Vyriausybès funkcijas, 1 punktas nustato, jog Vyriausybe bendradarbiauja su Respublikos Prezidentu, nustatant valstybès politiką bei prižiūrint jos ịgyvendinimą, o Ministras Pirmininkas vadovauja Vyriausybei, prižiūri jos darbą ir nukreipia jị Vyriausybès funkcijoms atlikti (155 str. 2 d.). Be to, svarbiems klausimams aptarti Respublikos Prezidentas gali sušaukti Vyriausybès posedžius ir jiems vadovauti, prašyti iš Ministro Pirmininko ataskaitų apie viešuosius reikalus (143 str.). Tačiau atsižvelgiant ị tai, jog ši kompetencija yra diskreciné ir nepatenka prie draudžiamų perduoti Prezidento teisių, galima manyti, kad Egipto Prezidentui, kaip ir Vokietijos bei Lietuvos prezidentams ar Jungtinès Karalystės monarchui, suteikiami tik nominalūs iggaliojimai vykdomosios valdžios, inter alia gynybos ministro, atžvilgiu, o Egipto valdymo sistemą iki $2013 \mathrm{~m}$. liepos $3 \mathrm{~d}$., kai buvo sustabdytas Konstitucijos galiojimas, galime apibūdinti kaip parlamentinę respubliką. Juo labiau kad konstituciškai už įstatymų igyvendinimą, valstybès saugumą, piliečių teisių ir valstybès interesų apsaugą yra atsakinga Egipto Vyriausybé, kuri turi turèti parlamento pasitikèjimą. Nors parlamentas nepasitikèjimą gali pareikšti ne visai Vyriausybei (kaip Vokietijoje ar Jungtineje Karalysteje), o tik Ministrui Pirmininkui ar ministrui (inter alia gynybos ministrui), kurie tokiu atveju privalo atsistatydinti (126 str.). Reikia pasakyti, kad $2013 \mathrm{~m}$. liepos $3 \mathrm{~d}$. vis dèlto egzistavo konstituciniai pagrindai parlamentui pasinaudoti nepasitikèjimo pareiškimo konstituciniu institutu kaip priemone ${ }^{22}$ atremti gynybos ministro sprendimus, radikaliai keičiančius valstybès valdymo sistemą.

Todèl toliau lygindami su kitu valstybių konstitucinèmis nuostatomis analizuosime, kas pagal Egipto Konstituciją turi igaliojimus vadovauti ginkluotosioms pajegoms ir kas valstybeje yra vyriausiasis ginkluotujų pajėgų vadas - prezidentas ar gynybos ministras.

\section{Valstybės vadovas ar gynybos ministras vyriausiasis ginkluotųų pajėgų vadas?}

Egipto Konstitucijos 146 straipsnis nustato, kad Respublikos Prezidentas yra vyriausiasis ginkluotųjų pajègų vadas. Tad remdamiesi vien lingvistiniu, t. y. tik Konstitucijos raidès, išsiaiškinimu, galètume teigti, kad ị klausimą atsakyta. Atsakymą, rodos, dar labiau sustiprina prieš tai minetas konstitucinis draudimas Prezidentui 
igyvendinti šią teisę per Ministrą Pirmininką, jo pavaduotojus ir ministrus (inter alia gynybos ministrą). Tačiau kaip vis dèlto vertinti konstitucinę nuostatą „vyriausiasis ginkluotuju pajegu vadas“ Egipto 2013 m. liepos 3 d. ịvykių kontekste - ar kaip suteikiančią teisę Prezidentui duoti privalomus nurodymus ginkluotosioms pajègoms, ar ne? Praktika tarsi pateikia neigiamą atsakymą i šị klausimą. Nors akivaizdu, kad demokratinèse valstybėse būtų neįsivaizduojama situacija, kai gynybos ministras vienasmeniškai skelbia, kur ir kaip yra panaudojamos ginkluotosios pajejgos. Tokiu atveju Konstitucijos 146 straipsnis netenka prasmès.

Jungtineje Karalystejje vyriausiasis ginkluotųju pajègų vadovas bent jau formaliai taip pat yra valstybės vadovas. Monarcho vardu skelbiamas karas ir sudaroma taika. Tačiau de facto Ministras Pirmininkas (su Kabineto, kurio nariu yra gynybos ministras, parama - aut. past.) sprendžia dèl kariuomenès panaudojimo, jos dislokavimo vietų. Netgi sprendimą dèl leidimo panaudoti atominị ginklą priima Ministras Pirmininkas ${ }^{23}$. Vis dèlto Ministras Pirmininkas palaiko nuolatinius Ministrų kabineto ir monarcho ryšius, pataria monarchui politikos klausimais, nors tik Vyriausybè (bet ne monarchas) atsako parlamentui. Tokị Ministro Pirmininko dominavimą R. Sturm prilygina Vokietijos Federalinio Kanclerio statusui, kuriam suteikti igaliojimai nustatyti valstybès politikos kryptis, ar net Jungtinių Amerikos Valstijų Prezidento statusui ${ }^{24}$.

Monarcho išimtinè teisè panaudoti ginkluotąsias pajègas gali būti teisminio nagrinèjimo objektu. Teismai gali nustatyti diskrecinių igaliojimų, kurie suteikiami pagal prerogatyvą, naudojimosi būdą, t. y. tokių igaliojimų egzistavimą ir apimtị isstatymuose („Karalius neturi tų igaliojimų, kurie nenustatyti įstatymu“) ${ }^{25}$, tačiau tai negali būti vertinama kaip teisẻ kontroliuoti ar ginčyti prerogatyvą ${ }^{26}$; teismai negali abejoti, ar Karūna protingai pasinaudojo savo diskrecija dèl ginkluotųjų pajègų disponavimo $^{27}$.

Tuo tarpu gynybos ministras ${ }^{28}$ pagal konstitucinę konvenciją taip pat yra Kabineto narys, kuri i pareigas (kaip ir kitus ministrus) Ministro Pirmininko teikimu skiria monarchas. Gynybos ministras su kitais Kabineto nariais kolegialiai atsakingas už

23 Vaitiekienè, E.; Mesonis, G. Lyginamoji konstitucinè teisè. Vilnius: Justitia, 2011, p. 267.

24 Sturm, R. Das politische System Grosbritanniens. Ismayr, W. (Hrsg.) Die politischen Systeme Westeuropas, 4., aktualisierte und uberarbeitete Auflage. Wiesbaden, 2009, p. 274.

25 Case of Proclamations [interaktyvus]. 1610 [žiūrèta 2013-08-05]. <http://www.bailii.org/ew/ cases/EWHC/KB/1610/J22.html>.

26 Council of Civil Service Unions \& others v. Minister for the Civil Service [interaktyvus]. 1985 [žiūrèta 2013-08-05]. <http://www.bailii.org/uk/cases/UKHL/1983/6.html>.

27 CfChina Navigation CoLtdv Attorney General [1932]; Chandlerv Directorof Public Prosecutions [1964]. Žr. Yasuo, H., supra note 1, p. 466.

28 Ginkluotosios pajegos yra valdomos Krašto apsaugos ministerijos, kuriai vadovauja gynybos ministras ir kuris atsako už bendrą jos veiklą. Šioje ministerijoje yra dar 5 ministrai, atsakingi už skirtingas valdymo sritis ministerijoje, bet gynybos ministras yra vyresnysis (pagal pareigas) ministras. Ministras Pirmininkas gali siūlyti ministrui atsistatydinti iš pareigų, o jei jis atsisako, kreipiasi ị monarchą, kad jị atleistų. 
visą Vyriausybės veiklą, apimančią klausimus ir dèl ginkluotųjų pajėgų panaudojimo, parlamente. Vis dèlto Jungtinès Karalystės monarchas išlieka kariuomenės, su karininkais ir personalu, prisiekiančiu ištikimybę monarchui, „galutine institucija“. Pagal Jungtinès Karalystės konstitucinę teisę, ginkluotosios pajègos yra pavaldžios Karūnai, tačiau ši teisè apribota sąlygos - nuolatinei kariuomenei išlaikyti reikia parlamento sutikimo $^{29}$, o dèl apmokestinimo ir lèšų skyrimo, t. y. biudžetinių asignavimų, ginkluotosioms pajejoms - parlamento patvirtinimo.

Vokietijos Federacinè Respublika išsiskiria tuo, kad Pagrindiniame İstatyme Federalinis Prezidentas nèra minimas kaip ginkluotųjų pajègų vadas. Vis dèlto gynybos srityje Vokietijos Pagrindinio Istatymo 60 straipsnio 1 dalyje numatyta, kad Federalinis Prezidentas skiria ir atleidžia karininkus ir puskarininkius, jeigu įstatymai nenumato kitaip. Tuo tarpu gynybos ministras turi teisę duoti įsakymus ir vadovauti ginkluotosioms pajègoms (65a str. 1 d.). Vokiškasis terminas „teise duoti įsakymus ir vadovauti“ („Befehls - und Kommandogewalt") kitų valstybių teisès sistemose nevartojamas. Atvirkščiai, kaip mateme, šiame kontekste yra vartojamas terminas $v y$ riausiasis ginkluotuju pajegu vadas, kurio pareigos paprastai priskiriamos valstybès vadovui, o valdymas daugeliu atvejų yra patikètas kompetentingam ministrui, t. y. gynybos ministrui. Tačiau vadovavimo teise, kai ji yra išskaidoma priklausomai nuo to valstybeje yra taikos ar nepaprastoji padètis pagal Pagrindinio Istatymo 65a ir 115b straipsnius, kitose valstybèse nenumatyta ${ }^{30}$. Karo atveju vadovavimo ginkluotosioms pajegoms teisè pereina Federaliniam Kancleriui (115 b str.). Gynybos ministras atsakingas už visus klausimus, susijusius su ginkluotųjų pajęgų valdymu ir organizavimu, ypač už klausimus, susijusius su struktūra, sušaukimu, dislokavimu, mokymais ir ịranga. Jis yra visų ginkluotųjų pajègų aukščiausiasis viršininkas ir drausmės institucija $^{31}$.

Federalinei Vyriausybei kaip kolegialiai institucijai konstituciškai suteikta (87a str. 4 d. ir 35 str. 3 d.) teisè ginkluotąsias pajègas dislokuoti šalies viduje, t. y. ji kolegialiai priima sprendimą, ar katastrofų ( 35 str. 3 d.) arba vidinès nepaprastosios padèties atveju (87a str. 4 d.) reikia dislokuoti. Bet kaip tai padaryti, t. y. operaciju valdymas ir konkrečių isakymų davimas, yra priskirta, kaip jau minèta, Federaliniam gynybos ministrui. Vokietijos Federalinio Konstitucinio Teismo jurisprudencija parodè, kad Federalinè Vyriausybè turi iniciatyvos teisę dislokuoti ginkluotąsias pajègas $^{32}$. Siauras sisteminis Pagrindinio İstatymo 65 straipsnio ${ }^{33}$ kontekstas leidžia daryti

29 Pagal 1689 m. Teisių Bilį, karalystės nuolatinès kariuomenės sušaukimas ir išlaikymas taikos metu, nebent tai būtų su parlamento sutikimu, prieštarauja ịstatymui.

30 Dürig, G.; Maunz, T. Kommentar zum Grundgesetz. Band V (Art. 54-85). 66. Ergänzungslieferung. Verlag C. H. Beck München, 2012, p. 1

31 Ibid., p. 42

32 Ibid., p. 37.

33 Federalinis Kancleris nustato politikos kryptis ir yra už tai atsakingas. Atsižvelgiant ị šias kryptis kiekvienas federalinis ministras savarankiškai vadovauja savo valdymo sričiai ir yra už ją atsakingas. Jeigu federalinių ministrų nuomonès skiriasi, sprendimą priima Federalinė Vy- 
išvadą, jog 65a straipsnyje įtvirtinta „teisè duoti įsakymus ir vadovauti“ yra kaip lex specialis bendros teisès vadovauti valdymo sričiai 65 straipsnio 2 sakinio prasme. Tačiau tada, kai nesutarimai tarp federalinių ministrų kyla dalyvaujant Federaliniam gynybos ministrui su jo ministerija susijusiais klausimai, jis negali viso Kabineto sprendimo dèl ginkluotụjų pajegų atremti savo vadovaujamos ministerijos kompetencija pagal 65a straipsní, nes pagal 65 straipsnio 3 sakini galutinio sprendimo prièmimo teisè apima visus su ministerija susijusius klausimus ${ }^{34}$.

Visais atvejais ginkluotụjų pajegų panaudojimą būtina nutraukti, jei to reikalauja Bundestagas arba Bundesratas (87a str. 4 d.). Konstituciškai ịtvirtinta ir daugiau ginkluotųjų pajègų panaudojimo kontrolès priemonių, kaip, pavyzdžiui, Pagrindinio Istatymo 45a, b straipsnis (parlamentinè kontrolè per Užsienio reikalų ir Gynybos komisijas; Gynybos igaliotinį), 87a straipsnio 1 dalies 2 sakinys (biudžeto asignavimai ginkluotosioms pajegoms), 115a straipsnis (Bundestago teisè konstatuoti gynybos padètí, kai kyla išorinè grèsmè).

Jungtinių Amerikos Valstijų Konstitucija ${ }^{35}$, kaip ir Prancūzijos 1958 m. Konstitucija $^{36}$, nustato, kad Prezidentas yra vyriausiasis ginkluotųjų pajegų vadas. JAV Konstitucijos kūrejjai ịtvirtindami vienasmenę vykdomąją valdžią kartu sudarè teisines galimybes iš jai pavaldžiu institucijų ar pareigūnų, taip pat ir gynybos sekretoriaus (ministro), reikalauti veiksmingo ịstatymų vykdymo ir išvengti ginčų, kurie kildavo dèl nuomonių skirtumų vykdomajai valdžiai esant daugianarei, kaip nagrinètos Vokietijos atveju.

JAV taip pat yra sudaromas Kabinetas, kuris daugelyje valstybių būtų ịvardijamas kaip vyriausybe ir kurio nariais yra departamentų ${ }^{37}$ vadovai - sekretoriai (ministrai), skiriami Prezidento Senato pritarimu, bet jų atleidimui Senato pritarimo nebereikia. Kabinetas nèra kolegialiai sprendimus priimanti institucija, tačiau teikia patariamus, rekomendacijas Prezidentui, nes visi sprendimai (tai pat gynybos srityje) priimami Prezidento vardu. Prezidentas teikia aukščiausius karinius laipsnius, skiria karo vadus, formuoja Generalinị štabą. Prezidentas formuoja užsienio politiką ir jai vadovauja $^{38}$. Vykdydamas savo igaliojimus Prezidentas leidžia ịsakymus, kuriuos tiesiogiai vykdo ir už vykdymą jam tiesiogiai atsiskaito jo paskirti pareigūnai, gynybos sekretorius ne išimtis. Gynybos departamentas (ministerija) yra didžiausia vykdomoji institucija, kuriai vadovauja gynybos sekretorius.

riausybè. Federalinis Kancleris vadovauja jų reikalams pagal Federalinės Vyriausybès priimtą ir Federalinio Prezidento patvirtintą reglamentą.

34 Dürig, G.; Maunz, T., supra note 30, p. 38.

35 Prezidentas yra vyriausiasis Jungtinių Valstijų kariuomenès ir jūrų laivyno, taip pat valstijų milicijos, kai ji šaukiama Jungtinių Valstijų tikrajai tarnybai atlikti, vadas (II straipsnio 2 skyrius).

36 Prancūzijos Respublikos Prezidentas yra vyriausiasis ginkluotųjų pajègų vadas, pirmininkauja nacionalinės gynybos aukščiausiosioms taryboms ir komitetams (15 str.).

37 Tačiau vykdomụjų agentūrų, kurios taip pat pavaldžios Respublikos Prezidentui, vadovai nèra Kabineto nariai.

Vaitiekienė, E.; Mesonis, G., supra note 23, p. 229. 
Pasak A. Hamiltono, Prezidento kaip pirmojo konfederacijos generolo ir admirolo, vyriausiojo ginkluotųjų pajègų vado igaliojimai turi apsiriboti vadovavimu ir ịsakymų davimu armijai ir kariniam jūrų laivynui ${ }^{39}$. Kaip Jungtinès Karalystès Ministras Pirmininkas, veikiantis monarcho vardu, ar Vokietijos gynybos ministras, JAV Prezidentas taip pat negali vienasmeniškai naudoti karinių pajègų. Jis negali paskelbti karo (tai gali padaryti tik Jungtinių Amerikos Valstijų Kongresas), bet gali siųsti karius ị užsienį dalyvauti taikos palaikymo ar panašiose operacijose. Tačiau tokị sprendimą per du ménesius turi patvirtinti Kongresas ${ }^{40}$.

Nors Prancūzijos $1958 \mathrm{~m}$. Konstitucijoje yra keli straipsniai, reglamentuojantys karo klausimus, jie suformuluoti gana neaiškiai ir kai kuriais atžvilgiais prieštaringai. Minèta, kad pagal Konstituciją Respublikos Prezidentas yra vyriausiasis ginkluotųju pajègų vadas ir kad jis pirmininkauja aukščiausiosioms nacionalinès gynybos taryboms bei komitetams (15 str.). Iš kitos pusès, 21 straipsnis nustato, kad Ministras Pirmininkas yra atsakingas už nacionalinę gynybą. Vis dèlto atrodo, kad Konstitucija valstybès gynybos srityje Prezidentui suteikia gana stiprius igaliojimus.

Penktojoje Respublikoje reaguojant $\mathfrak{i}$ neatidèliotinas vidaus politinio nestabilumo ir paplitusio dekolonizacinio karo aplinkybes valdymo sistema suteikè Prezidentui reikiamus igaliojimus ${ }^{41}$ - imtis būtinų priemonių reaguojant ị nacionalinę nepaprastąją padètį ${ }^{42}$ (16 str. 1 d.), taip pat teisę igyvendinti šiuos igaliojimus be ministro kontrasignacijos.

Prezidento „pasidalinti igaliojimai“ apima jo, kaip vyriausiojo ginkluotųjų pajègu vado, igaliojimus. Pavyzdžiui, pagal Konstituciją Prezidentas skiria civilinius ir karinius valstybės pareigūnus (13 str. 2 d.), pirmininkauja Gynybos tarybai, kuri priima pačius svarbiausius sprendimus, susijusius su nacionaline gynyba (15 str.). Respublikos Prezidentas, kaip vyriausiasis ginkluotųjų pajegų vadas, gali duoti ịsaky-

Yasuo, H., supra note 1, p. 468.

40 Amerikos istorijoje nuo jos ịkūrimo yra gausu atvejų, kai Prezidentas išsiuntė ginkluotąsias pajègas ị užsienị be išankstinio Kongreso leidimo. Kongresas skelbẻ karą tik penkiais atvejais per visą Amerikos istoriją: 1812 m. karas, 1846-1848 m. Meksikos ir Amerikos karas, 1898 m. Ispanijos ir Amerikos karas, Pirmasis pasaulinis karas, Antrasis pasaulinis karas. Visuose šiuose konfliktuose karas buvo paskelbtas po to, kai karo veiksmai jau buvo vykdomi. Žr. Yasuo, H., supra note 1, p. 469.

41 İskaitant teisę skirti Ministrą Pirmininką (8 str. 1 d.), paleisti Nacionalinị susirinkimą (12 str. 1 d.), siūlyti nacionalinius referendumus (11 str.). Žr. Yasuo, H., supra note 1, p. 472.

42 Tačiau prieš imdamasis tokių priemonių Prezidentas turi tartis su Ministru Pirmininku, parlamento rūmų pirmininkais ir Konstitucine Taryba. Jų nuomonè Prezidento nesaisto, tačiau Konstitucinès Tarybos nuomonè skelbiama ir jeigu ji neigiama, o Prezidentas jos nepaiso, jis gali būti apkaltintas valstybès išdavimu. Be to, valstybės vadovas apie priemones turi informuoti tautą. Pažymètina, kad 2008 m. konstitucine pataisa minètasis Konstitucijos 16 straipsnis papildytas tokia nuostata: po trisdešimties dienų, kai imtos taikyti ypatingosios priemonès, Nacionalinio Susirinkimo Pirmininkas, Senato Pirmininkas, 60 deputatų ar 60 senatorių gali kreiptis ị Konstitucinę Tarybą su prašymu patikrinti, ar ir toliau yra visos sąlygos, numatytos Konstitucijos 16 str. 1 d. Žr. Jarašiūnas, E., supra note 7, p. 339. 
mus dèl branduolinès jègos įsipareigojimų, kuriuos privalo vykdyti generalinio štabo $\operatorname{vadas}^{43}$. Vadinasi, teisè spręsti dèl branduolinès jègos panaudojimo išimtinai priklauso tik Prezidentui, o Jungtineje Karalysteje - Ministrui Pirmininkui, kuris šią teisę, kaip minèta, igyvendina monarcho, kaip vyriausiojo ginkluotųjų pajègų vado, vardu.

Nors ir manoma, kad Prancūzijos Ministras Pirmininkas atsakingas už nacionalinę gynybą (21 str.), paprastai susilaikoma nuo bet kokio prezidentinių galių, kuriomis jis gali tikètis vieną dieną naudotis (nes pagal Konstitucijos 13 ir 21 str. Prezidentas gali perduoti igyvendinti kai kuriuos savo igaliojimus), ribojimo. Ministras Pirmininkas koordinuoja ministerijų darbą, kontroliuoja jas, o Krašto apsaugos ministerija, vadovaujama krašto apsaugos ministro, atsakinga už gynybos politikos, kurią nustato Respublikos Prezidentas, kaip vyriausiasis ginkluotųjų pajègų vadas, igyvendinimą. Vadinasi, Prancūzijos Prezidentas (kaip ir JAV, o Jungtinèje Karalystejje kaip Ministras Pirmininkas monarcho vardu ar Vokietijoje - Federalinis Kancleris (karo padèties metu) ir gynybos ministras (taikos metu) - aut. past.) lieka pagrindiniu sprendimų prièmejju ${ }^{44}$. Tačiau Prancūzijos Konstitucijos 35 straipsnio 1 dalis vis dèlto reikalauja, kad karo paskelbimui būtų pritarta parlamente, bet pati karo paskelbimo teise priklauso vykdomajai valdžiai. Beje, 35 straipsnis nereikalauja, kad parlamentas karo paskelbimui pritartų iš anksto ${ }^{45}$.

Šiame kontekste paminètinas ir Lietuvos Respublikos Konstitucijos 140 straipsnis, pagal kurį Lietuvos valstybės vadovas taip pat yra vyriausiasis valstybės ginkluotụjų pajègų vadas (2 dalis). Respublikos Prezidentas vadovauja Valstybės gynimo tarybai, skirtai svarbiausiems valstybės gynybos klausimams svarstyti ir koordinuoti, suteikia aukščiausius karinius laipsnius, o Seimo pritarimu skiria ir atleidžia kariuomenès vadą (Konstitucijos 84 str. 14, 15 p.), kuris yra aukščiausiasis valstybės karinis pareigūnas, kariniais klausimais atstovaujantis Lietuvos kariuomenei. Vis dèlto ordinariniuose teisès aktuose ${ }^{46}$ itvirtinta, jog kariuomenès vadas tiesiogiai pavaldus krašto apsaugos ministrui. Todèl Prezidento, kaip vyriausiojo ginkluotųjų pajëgu vado, vaidmuo, ko gero, yra daugiau kaip simbolinis ženklas. Maža to, G. Vedel ${ }^{47}$ parlamentinès respublikos prezidentinị „vyriausiojo ginkluotųjų pajègų vado" titulą charakterizuoja "tik kaip garbès titulą", teigdamas, kad tikrasis vadovavimas nacionalinei gynybai, ar tai būtų taikos, ar karo metas, priklauso Ministrui Pirmininkui, ministrams, atsakingiems už karo ministeriją, ir Kabinetui.

Paskelbus karo padètí, Respublikos Prezidento dekretu kariuomenès vadas skiriamas visų valstybės ginkluotųjų pajègų vadu ${ }^{48}$, pavaldžiu gynybos veiksmų civilinei

Yasuo, H., supra note 1, p. 473.

Ibid., p. 473.

Ibid., p. 473.

Lietuvos Respublikos nacionalinio saugumo pagrindų įstatymas. Valstybės žinios. 1997, Nr. 2-16. 8 skyrius; Lietuvos Respublikos krašto apsaugos sistemos organizavimo ir karo tarnybos ịstatymas. Valstybès žinios.1998, Nr. 49-1325. 13 str. 4 d.

Vedel, G. Manuelélémentaire de Droit Constitutionnel. Recueil Sirey, 1949, p. 516.

Būtų galima kelti ịstatymo „visų valstybès ginkluotųjų pajègų vadas“ ir konstitucinès „vyriausiasis valstybès ginkluotųjų pajęgų vadas“ nuostatų suderinamumo klausimą ir ar Respublikos 
vadovybei ${ }^{49}$, kurią sudaro Respublikos Prezidentas ir krašto apsaugos ministras. Šis ordinarinis reguliavimas atitinka Lietuvos Konstitucinio Teismo doktriną, kad karinès valstybès institucijos negali turèti pirmenybės prieš civilines valstybès institucijas, karinių valstybès institucijų bei jų pareigūnų sprendimai turi būti grindžiami civilinių valstybès institucijų sprendimais, karinès valstybès institucijos turi būti atskaitingos civilinems valstybès institucijoms ir jų kontroliuojamos ${ }^{50}$. Ši nuostata kyla iš konstitucinio reikalavimo, kad Lietuvos valstybès valdžia būtų demokratiškai organizuota, iš konstitucinio atviros, teisingos, darnios pilietinès visuomenès imperatyvo, konstitucinio atsakingo valdymo principo.

Todèl suprantama, kad pagal Konstitucijos 141 straipsni asmenys, atliekantys tikrąją karo arba alternatyviąją tarnybą, taip pat neišèję i atsargą krašto apsaugos sistemos, policijos ir vidaus tarnybos karininkai, puskarininkiai ir liktiniai, kitų sukarintų ir saugumo tarnybų apmokami pareigūnai negali būti Seimo nariais ir savivaldybių tarybų nariais, jie negali užimti renkamų ar skiriamų pareigų civilinëje valstybinèje tarnyboje. Minètą karinių valstybès institucijų atskaitingumą civilinèms valstybès institucijoms ir jų kontrolę bei civilinès ir karinès valdžios atskyrimą (pareigų nesuderinamumą) iliustruoja Konstitucijos 140 straipsnio 3 dalis: krašto apsaugos ministru negali būti neišejęs ị atsargą karys; už valstybès ginkluotųjų pajègų tvarkymą ir vadovavimą joms Seimui yra atsakingi Vyriausybė, krašto apsaugos ministras, kariuomenès vadas. Galime teigti, kad Seimas vykdo ne tik krašto apsaugos ministro, bet ir ginkluotųjų pajègų parlamentinę kontrolę.

Paminètina ir tai, kad Seimas yra konstituciškai igaliotas priimti galutinius sprendimus pagrindiniais valstybės gynimo (apsaugos) klausimais: dèl karo ar nepaprastosios padėties ịvedimo ir atšaukimo, mobilizacijos ar demobilizacijos paskelbimo, ginkluotųjų pajègų panaudojimo (67 str. 20 p., 142 str. ir 144 str. 1 bei 2 d.). Net jei Prezidentas ir priima šiais klausimais sprendimus, yra ịpareigotas pateikti juos tvirtinti artimiausiam Seimo posedžiui (84 str. 16 p., 142 str.). Vis dèlto be parlamen-

Prezidentas vyriausiuoju valstybės ginkluotųjų pajėgų vadu yra tik taikos metu. Tačiau tai tik pirminis nesuderinamumo įspūdis, kadangi sąvoka „visų valstybės ginkluotujų pajègų vadas“ atitinka situaciją, kai ịvedus karo padetį ar ginkluotos gynybos nuo agresijos (karo) atveju kariuomenès vadas tampa ne tik kariuomenès, bet ir kitos ginkluotosios pajègos (Valstybės sienos apsaugos tarnybos, Viešojo saugumo tarnybos, kovinių Lietuvos šaulių sąjungos būrių ir kitų kovinių piliečių bei jų organizacijų ginkluoto pasipriešinimo (partizanų) vienetų) vadu. Prezidentas savo kaip vyriausiojo ginkluotųjų pajègų vado konstitucinio statuso nepraranda.

49 Lietuvos Respublikos krašto apsaugos sistemos organizavimo ir karo tarnybos įstatymas, supra note 46,13 str. 9 d.

50 Lietuvos Respublikos Konstitucinio Teismo 2011 m. kovo 15 d. nutarimas „Dèl tarptautiniu karinių operacijų, pratybų ir kitų karinio bendradarbiavimo renginių", supra note 10; Lietuvos Respublikos Konstitucinio Teismo 2004 m. gruodžio 13 d. nutarimas „Dèl valstybès tarnybos“, supra note 10; Lietuvos Respublikos Konstitucinio Teismo 2002 m. gruodžio 24 d. nutarimas „Dèl savivaldos atstovaujamųjų ir vykdomųjų institucijų kompetencijos“, supra note 10; Lietuvos Respublikos Konstitucinio Teismo 1996 m. gegužès 29 d. sprendimas „Dèl pradètos teisenos nutraukimo“, supra note 10. 
tinio pritarimo tik taikos metu ir tik Respublikos Prezidentas priima sprendimus dèl ginkluotųjų pajègų išdèstymo ir tik jis savo dekretu gali duoti įsakymus dèl ginkluotųjų pajègų dalinių perkèlimo ị kitą dislokavimo vietą ${ }^{51}$.

Krašto apsaugos ministras pagal Konstitucijos 96 straipsnio 2 dali ir 98 straipsnio 1 dali vadovauja jam pavestai valdymo sričiai, krašto apsaugos klausimais atstovauja Vyriausybei, sprendžiant svarbiausius krašto apsaugos sistemos personalo, kariuomenès plètros ir tvarkymo bei vadovavimo jai klausimus ${ }^{52}$.

Ankstesnè valstybių analizė parodè, kad gynybos (krašto apsaugos) ministras yra atsakingas tik už vadovavimą gynybos (krašto apsaugos) ministerijai. Toks asmuo skiriamas iš civilių asmenų ministro pirmininko arba valstybės vadovo, kaip vyriausiojo ginkluotųjų pajègų vado, ir turi turèti pasitikejimą parlamentinès daugumos, kuriai atsiskaito vienasmeniškai arba kolegialiai, priklausomai nuo valstybès valdymo formos. Jo veiksmams taikoma parlamentinè (tautos atstovybės) kontrolè. Prezidentinèje respublikoje gynybos sekretorius (ministras) atsiskaito tiesiogiai valstybès vadovui.

Tuo tarpu Egipte ne Respublikos Prezidentas, bet gynybos ministras yra ginkluotųjų pajėgų vadas, be to, paskirtas iš karininkų (195 str.). Jis, kaip ir kiekvienas ministras, parengia savo ministerijos bendrąją politiką, prižiūri jos igyvendinimą, duoda nurodymus ir atlieka kontrolę, tačiau atsižvelgiant ị valstybės viešąą politiką (160 str.), kuri kaip minèta, nustatoma Vyriausybei bendradarbiaujant su Prezidentu. Daugiau Konstitucija jo veiksmų galių ar kontrolès būdų, išskyrus minètą nepasitikèjimo institutą, nepateikia. Atsižvelgiant ị tai, kad gynybos ministras yra ir ginkluotųjų pajègų vadas, galima manyti, kad turèdamas dvigubą teisinị statusą turi kompetenciją atlikti kontrolę ir duoti nurodymus ne tik savo vadovaujamai ministerijai, bet ir ginkluotosioms pajègoms (kariuomenei).

Tačiau dėmesị atkreipia Konstitucijos trečioji dalis, kurioje, minèta, yra pateikiama valstybès valdžios institucijų sistema. Be bikameralinio parlamento, dualistinès vykdomosios bei teisminès valdžių, tos pačios trečios dalies penktame skyriuje nustatyti nacionalinio saugumo ir gynybos institucijų (Nacionalinio saugumo tarybos; Ginkluotųjų pajėgų, kurioms vadovauja gynybos ministras; Valstybès gynimo tarybos; karinių teismų; policijos ${ }^{53}$ ) konstituciniai pagrindai. Tokio pobūdžio institucijų priskyrimas prie valstybinės valdžios yra neịprastas demokratinėms valstybėms. Kartu implikuoja išvadą, kad minètas institucijas galime laikyti viena iš valstybès valdžių, per kurias tauta igyvendina savo suverenitetą. Maža to, Konstitucija expressis verbis nedetalizuoja, kokia šių institucijų priimamų sprendimų teisinè galia, kam jos atskaitingos ir kas gali jas kontroliuoti. Neaišku ir tai, ar gynybos ministro, kaip ginkluotųjų pajègų vado, vadovavimas ginkluotosioms pajėgoms ir jų kontrolè neturi

51 Lietuvos Respublikos nacionalinio saugumo pagrindų ịstatymas, supra note 46, 8 skyrius.

52 Žalimas, D., supra note 9, p. 931.

53 Policijos vyriausiasis vadovas yra Prezidentas. 
remtis Vyriausybės ir Prezidento nustatyta bendra valstybės politika bei jai neprieštarauti, taip pat ir pačios gynybos ministerijos nustatyta bendrąja politika, už kurios vykdymą gynybos ministras vis dèlto atsiskaito parlamentui. Kitaip tariant, valdžių padalijimo principas nèra išsamiai ịtvirtintas Konstitucijoje.

Iš kitos pusès, Egipto Respublikos Prezidentas, kaip vyriausiasis ginkluotųjų pajègų vadas, skiria bei atleidžia civilius ir karinius tarnautojus (147 str.). Pasikonsultavęs su Vyriausybe Respublikos Prezidentas skelbia nepaprastąją padetį. Tokia nepaprastosios padèties deklaracija turi būti patvirtinta abejų parlamento rūmų narių balsụ dauguma ir negali ịtvirtinti ilgesnio nei šešių mènesių laikotarpio. Terminas gali būti pratęstas panašiam laikotarpiui, jei tam pritaria žmonès referendume (148 str.). Be to, Respublikos Prezidentas negali vienasmeniškai nutaręs paskelbti ir karo arba siųsti ginkluotąsias pajėgas už šalies teritorijos. Prieš priimdamas tokị sprendimą valstybès vadovas turi pasikonsultuoti su Nacionaline gynimo taryba bei gauti Atstovų tarybos pritarimą narių balsų dauguma. Tad Egipto Prezidentas, skirtingai nei Lietuvos ar Prancūzijos, turi a priori gauti iš tautos atstovybès pritarimą panaudoti ginkluotąsias pajègas. Tai galime vertinti kaip tam tikrą atsvarą Prezidento turimiems kariniams igaliojimams, apsisaugojimą nuo vienasmeniškų valstybès vadovo sprendimų skelbti karą ar dislokuoti ginkluotąsias pajegas užsienyje. Svarbu ir tai, kad šių Prezidento sprendimų legitimacija turi būti atliekama institucijos, ịkūnijančios tautos atstovybę.

Parlamentinio pritarimo panaudoti ginkluotąsias pajegas būtinumą galima palaikyti Kanto argumentu, kad piliečiai „visuomet turi būti laikomi valstybès bendros istatymų leidybos nariais (ne tik kaip priemone, bet ir patys savaime tikslu) ir todèl jie duoda savo laisvą sutikimą per savo atstovus ne tik kariauti apskritai, bet ir dèl kiekvieno konkretaus karo paskelbimo. Tik esant šiai ribojančiai sąlygai valstybės gali liepti jiems tarnauti labai jiems pavojingu būdu"s4.

Tad vèlgi galime susimąstyti dèl Egipto gynybos ministro $2013 \mathrm{~m}$. liepos $3 \mathrm{~d}$. veiksmų (panaudoti ginkluotąsias pajègas Prezidentui pašalinti iš pareigų) konstitucingumo. Nors pagal Konstituciją gynybos ministras yra ginkluotųjų pajègų vadas, o valstybès vadovas - vyriausiasis ginkluotụjų pajègų vadas, tačiau, kaip parode užsienio valstybių analizè, tai nepaneigia konstitucinès būtinybès tikroje demokratinèje valstybèje gauti tautos atstovybès pritarimą ar bent jau jos atsiklausti prieš panaudojant ginkluotąsias pajègas. Egipto Prezidentui tokia konstitucinè pareiga numatyta, o gynybos ministro atžvilgiu Konstitucija est silentium.

Todèl paskutinis klausimas, kurị reikètų aptarti, ar Egipto gynybos ministrui suteikta konstitucinẻ teise pašalinti Respublikos Prezidentą iš pareigų, o Aukščiausiojo Konstitucinio Teismo teisèją paskirti laikinai eiti jo pareigas?

54 Kant, I. The Metaphysics of Morals. Mary Gregor (transanded), Practical Philosophy. 1996, p. 484 . 


\section{Ar gynybos ministras turi konstitucinę teisę pašalinti Respublikos Prezidentą iš pareigų?}

Demokratinèse valstybèse legalus būdas užimti Respublikos Prezidento pareigas, kaip ir suformuoti tautos atstovybę, - rinkimai. Be to, iš pačios konstitucijos kyla, kaip nurodo, V. Sinkevičius ${ }^{55}$, „rinkimų būtinumas“ bei „periodiškumas“. Egipto Konstitucija skelbia, kad valstybė yra demokratinè (1 str.), o Prezidentas renkamas 4 metams (133 str.), remiantis demokratiniais rinkimų principais: tiesioginiai, slapto balsavimo (136 str.). Tad pagal Konstituciją pasibaigus valstybès vadovo pareigas ejjusio asmens kadencijai tik tauta gali apsispręsti išrinkti eiti Respublikos Prezidento pareigas tą pati (kai jis kandidatuoja antrai kadencijai) arba kitą asmeni, jeigu pirmtako atlikti darbai neatitiko tautos lūkesčių ir interesų.

Kaip minèta, Egipto ginkluotosios pajègos laiko nušalintąji Prezidentą, nes prokurorai gali pateikti kaltinimus dèl jo ir kitų kalinių pabėgimo iš kalejjimo per sukilimą $2011 \mathrm{~m}$. Vadinasi, valstybės vadovas ginkluotųu pajègų ir gynybos ministro yra apkaltintas ne tik dèl šalyje kilusios politinès krizès bei dèl to nušalintas nuo pareigų, bet ir dèl nusikalstamos veikos. Tačiau reikia pabrèžti, kad „žmogaus ir piliečio teisėms garantuoti reikalingos ginkluotosios pajègos. Šios pajejgos ịkurtos visų naudai, o ne asmeniniams interesams tų, kuriems jos patikètos ${ }^{\text {“56 }}$.

Pirmiausiai paminètina, kad valstybių konstitucijos nustato aiškius pagrindus, kada valstybès vadovas netenka igaliojimų. Paprastai tai būna: mirtis, atsistatydinimas, pilietybės praradimas, negalejimas eiti pareigų dèl sveikatos būklès ar pan. Vienas iš tokių pagrindų taip pat yra apkalta. Konstitucinès teisès doktrinoje pateikiami keli valstybès vadovo pašalinimo ir pareigų apkaltos proceso tvarka modeliai ${ }^{57}$, bet

55 Sinkevičius, V. Seimo narių rinkimai: kai kurie teoriniai ir praktiniai rinkimų teisès aspektai. Jurisprudencija. 2008, 9(111): 55.

56 Prancūzijos 1789 m. Žmogaus ir piliečio teisių deklaracijos 12 straipsnis.

57 Prancūzijos Prezidentas gali būti pašalintas iš pareigų tik dẻl savo pareigų nevykdymo, akivaizdžiai nesuderinamo su jo mandatu. Sprendimą dèl pašalinimo iš pareigų priima parlamentas, veikiantis kaip Aukštasis Teismas. Tokia koncepcija ịtvirtinta tik 2007 m. vasario 23 d. konstitucine pataisa. Žr. Jarašiūnas, E., supra note 7, p. 446.

$J A V$ Senatui priklauso išimtinè teisè svarstyti visas apkaltos bylas (po to, kai Atstovų rūmai inicijuoja apkaltą). Tokiais atvejais posėdžiaujantys senatoriai privalo prisiekti. Jeigu apkalta taikoma Jungtinių Valstijų Prezidentui, posedžiui pirmininkauja Aukščiausiojo Teismo pirmininkas; nè vienas pareigūnas negali būti nuteistas, jeigu nuteisimui pritaria mažiau nei du trečdaliai poseddyje dalyvaujančių Senato narių (Konstitucijos I straipsnio 3 skyrius). Prezidentas, viceprezidentas ir visi Jungtinių Valstijų pareigūnai gali būti pašalinti iš pareigų, kai apkaltos procedūra jie yra pripažįstami kaltais dèl valstybès išdavimo, kyšininkavimo ar kito sunkaus arba nesunkaus nusikaltimo padarymo (Konstitucijos II straipsnio 4 skyrius.).

Vokietijos Bundestago arba Bundesrato siūlymu Federalinis Konstitucinis Teismas gali nuspręsti, kad Federalinis Prezidentas yra kaltas dèl tyčinio Pagrindinio İstatymo ar kito federalinio įstatymo pažeidimo, ir todèl jị pašalinti iš pareigų (Pagrindinio İstatymo 61 str.).

Jungtineje Karalysteje „monarchas negali neteisingai pasielgti“, o tai priskiriama prie asmeni- 
paprastai procesas pradedamas tautos atstovybès iniciatyva. Be to, valstybės vadovas netekęs savo įgaliojimų praranda ir imunitetą, todèl jam už padarytas nusikalstamas veikas bendra tvarka gali būti taikoma teisinè atsakomybè.

Nors Egipto Konstitucija eksplicitiškai ir nesuteikia Prezidentui imuniteto, iš kitos pusès, yra apkaltos instituto konstituciniai pagrindai. Egipte inicijuoti apkaltą Respublikos Prezidentui dẻl sunkaus nusikaltimo ar valstybès išdavimo gali ne mažiau kaip vienas trečdalis Atstovų tarybos narių, t. y. kaip ir Prancūzijoje, JAV, Vokietijoje ar Lietuvoje inicijuoja tautos atstovybè. Tačiau tokiai iniciatyvai turi pritarti ne mažesnè kaip dviejų trečdalių Atstovų tarybos narių balsų dauguma ir tik tada galima vykdyti apkaltą. Kai tik priimamas sprendimas pradèti apkaltą, Respublikos Prezidentui laikinai draudžiama vykdyti savo pareigas, kol bus priimtas teismo sprendimas. O kol Prezidentas negali atlikti savo pareigų, jas vykdo Ministras Pirmininkas (153 str.). Respublikos Prezidentas yra teisiamas specialaus teismo ${ }^{58}$; baudžiamasis kaltinimas tokiame procese palaikomas generalinio prokuroro. Prièmus apkaltinamąji nuosprendị Respublikos Prezidentas yra atleidžiamas iš pareigų ir skiriama baudžiamoji sankcija (152 str.).

Kai Prezidento vieta lieka laisva dèl atsistatydinimo, mirties, nuolatinio nedarbingumo arba dèl kitos priežasties (šiuo atveju ir dèl apkaltos), Atstovų tarybos pirmininkas, bet ne konstitucinès justicijos institucijos teisèjas, laikinai eina Prezidento pareigas. Toks laikinas Prezidento pareigų ejimas numatytas ir nagrinejjamų valstybių konstitucinėse sistemose: Vokietijos Federalinio Prezidento pareigas eina kasmet renkamas Bundesrato Pirmininkas; JAV ir Prancūzijoje Prezidento ịgaliojimus prezidento vakansijos atveju vykdo aukštųjų parlamento rūmų pirmininkas; Lietuvos Prezidento pareigas taip pat laikinai eina Seimo Pirmininkas.

Tad pritariant Dž. Locko minčiai, kad „niekas negali atiduoti daugiau valdžios negu pats jos turi, ir tas, kuriam neduota valdžia $<\ldots>$ negali duoti kitam tokios valdžios ${ }^{\text {“59 }}$, galiausiai tenka konstatuot, kad Egipto Konstitucija nesuteikia gynybos ministrui teisès pašalinti Respublikos Prezidentą iš pareigų, o konstitucinès justicijos institucijos teisèją paskirti laikinai eiti Prezidento pareigas. Todèl vietoj šių gynybos ministro sprendimų reikejo pritaikyti apkaltos ir / arba rinkimų institutą. Tokiu atveju nekiltų abejonių dèl gynybos ministro veiksmų konstitucingumo, o kartu ir dèl demokratiškumo.

nių jo prerogatyvų. Praktikoje tai reiškia monarcho asmens teisminị imunitetą. Žr. Kavoliūnienè, I.; Vainiute, M. Jungtinès Didžiosios Britanijos ir Šiaurès Airijos Karalystès konstitucinè sistema. Europos Sajungos valstybiu nariu konstitucinés sistemos. Vilnius: Mykolo Romerio universitetas. 2012, p. 400.

58 Tokiam teismui vadovauja Aukščiausiosios teismų tarybos pirmininkas, o nariai yra ilgiausią darbo stažą turintys Aukščiausiojo Konstitucinio Teismo ir Valstybinès tarybos pirmininkų pavaduotojai, du ilgiausią darbo stažą turintys Apeliacinio teismo pirmininkai. Lokas, Dž. Esè apie pilietinę valdžią. Vilnius: Mintis, 1992, p. 29. 


\section{Išvados}

1. Šiuo metu Egipte vykstantys procesai - svarbus demokratiškumo testas, kuri kol kas valstybei sunku išlaikyti. Žvelgiant i 2012 m. gruodžio 26 d. Egipto Arabų Respublikos Konstitucijoje numatytą valstybès valdžių sistemą, matyti, kad Konstitucijoje trūksta aiškesnio valdžių padalijimo, todèl stokojama demokratiškumo. Ivairios karinés tarybos bei ginkluotosios pajègos yra lygiavertès kitoms trims valstybės valdžioms (įstatymų leidžiamajai, vykdomajai ir teisminei). Tačiau demokratinèje valstybeje karinès valstybès institucijos negali būti priskiriamos prie valstybès valdžios institucijų, o juo labiau turèti pirmenybès prieš jas. Priešingai, karinės valstybès institucijos turi būti atskaitingos civilinèms valstybès institucijoms ir jų kontroliuojamos, o jų sprendimai turi būti grindžiami civilinių valstybės institucijų sprendimais.

2. Egipto gynybos ministro $2013 \mathrm{~m}$. liepos 3 d. veiksmai atlikti pažeidžiant konstitucines nuostatas, pagal kurias tauta nusistatė gyventi, patvirtindama Konstituciją referendume. Pagal Konstituciją gynybos ministrui nenumatyta teisé sustabdyti Konstitucijos galiojimą. Egipto Konstitucija taip pat nesuteikia gynybos ministrui teisès pašalinti Respublikos Prezidentą iš pareigų, o konstitucinès justicijos institucijos teisèją paskirti laikinai eiti Prezidento pareigas. Be to, išspręsti valstybejje kilusią politinę krizę ir išvengti Konstitucijos pažeidimų buvo galima ịgyvendinant kitas konstitucines priemones (nepasitikejimo, apkaltos arba rinkimų institutus).

3. Parlamentinèse respublikose (Egipte, Lietuvoje, išskyrus Vokietiją) ir konstitucinèse monarchijose (Jungtinèje Karalystėje) valstybės vadovas dažniausiai yra tik nominalus vyriausiasis ginkluotųjų pajegų vadas, o prezidentinèse (JAV) ir pusiau prezidentinèse (Prancūzija) respublikose valstybès vadovui suteikti platūs vienasmeniai igaliojimai dèl ginkluotụjų pajegu panaudojimo. Nors valstybès gynimo sritis daugiausia priklauso vykdomosios valdžios kompetencijai, tačiau nagrinètų valstybių konstitucinès sistemos parodè, jog sprendimą panaudoti ginkluotąsias pajègas turi patvirtinti parlamentas, kaip tautos atstovybè.

4. Valstybės vadovo, kaip vyriausiojo valstybės ginkluotụjų pajègų vado, konstitucinis statusas implikuoja jo igaliojimus strateginiu lygmeniu vadovauti valstybès ginkluotosioms pajègoms, skirti aukščiausius ginkluotųjų pajęgų vadus ir karininkus. Gynybos ministras (sekretorius) vadovauja savo valdymo sričiai (gynybos ministerijai (departamentui) ir yra už ją atsakingas parlamente kolegialiai su vyriausybe (Vokietija, Jungtinè Karalystė, Lietuva, Prancūzija) arba asmeniškai (Egiptas, Lietuva, Prancūzija), o prezidentinèse respublikose - tik valstybès vadovui (JAV). Gynybos ministrui paprastai priskiriami ne vadovavimo ginkluotosioms pajegoms, bet valdymo klausimai, susiję su ginkluotųjų pajègų struktūros nustatymu, mokymais, sušaukimu ir pan.

Kristina Kenstavičienè dèkoja už Lietuvos mokslo tarybos projekto „Studentu mokslines veiklos skatinimas"(VP1-3.1-ŠMM-01-V-02-003) paramą. Projektas yra finansuojamas pagal Žmogiškuju ištekliu plètros veiksmu programos 3 prioriteta „Tyrëju gebejimu stiprinimas" iš Europos socialinio fondo ir Lietuvos Respublikos valstybès biudžeto lëšu. 
Kristina Kenstavičiene acknowledge support by project "Promotion of Student Scientific Activities" (VP1-3.1-ŠMM-01-V-02-003) from the Research Council of Lithuania. This project is funded by the Republic of Lithuania and European Social Fund under the 2007-2013 Human Resources Development Operational Programme's priority 3.

\section{Literatūra}

Barnett, H. Constitutional and administrative law. London: Cavendish Publishing Limited. 2004.

Case of Proclamations [interaktyvus]. 1610 [žiūrèta 2013-08-05]. <http://www.bailii.org/ew/cases/EWHC/KB/1610/J22. html>.

Council of Civil Service Unions \& others v. Minister for the Civil Service [interaktyvus]. 1985 [žiūrèta 2013-0805]. <http://www.bailii.org/uk/cases/ UKHL/1983/6.html>.

Dürig, G.; Maunz, T. Kommentar zum Grundgesetz. Band V (Art. 54-85). 66. Ergänzungslieferung. Verlag C. $\mathrm{H}$. Beck München, 2012.

Yasuo, H. War Powers. The Oxfordhandbook of comparative constitutional law. Oxford: Oxford University Press, 2012.

Jarašiūnas, E. Prancūzijos Respublikos Prezidento konstitucinis statusas. Prezidentas valstybinés valdžios instituciju sistemoje. Vilnius: MES, 2011.

Kant, I. The Metaphysics of Morals. In Mary Gregor (transanded), Practical Philosophy (1996).

Kavoliūnienė, I.; Vainiutè, M. Jungtinès Didžiosios Britanijos ir Šiaurès Airijos Karalystès konstitucinè sistema. Europos Sajungos valstybiu nariu konstitucinés sistemos. Vilnius: Mykolo Romerio universitetas. 2012.

Lietuvos Respublikos Konstitucinio Teismo 1996 m. gegužès 29 d. sprendimas „Dèl pradètos teisenos nutraukimo“. Valstybès žinios. 1996, Nr. 57-1364.
Lietuvos Respublikos Konstitucinio Teismo $2002 \mathrm{~m}$. gruodžio $24 \mathrm{~d}$. nutarimas „Dèl savivaldos atstovaujamųjų ir vykdomųjų institucijų kompetencijos". Valstybès žinios. 2003, Nr. 19-828.

Lietuvos Respublikos Konstitucinio Teismo $2004 \mathrm{~m}$. gruodžio $13 \mathrm{~d}$. nutarimas „Dèl valstybès tarnybos“. Valstybès žinios. 2004, Nr. 181- 6708; Atitaisymas: 2004, Nr. 186.

Lietuvos Respublikos Konstitucinio Teismo 2011 m. kovo 15 d. nutarimas „Dèl tarptautinių karinių operacijų, pratybų ir kitu karinio bendradarbiavimo renginių“. Valstybès žinios. 2011, Nr. 321503.

Lietuvos Respublikos krašto apsaugos sistemos organizavimo ir karo tarnybos i̇statymas. Valstybès žinios.1998, Nr. 49-1325.

Lietuvos Respublikos nacionalinio saugumo pagrindų ìstatymas. Valstybès žinios. 1997, Nr. 2-16.

Lokas, Dž. Esè apie pilietinę valdžią. Vilnius: Mintis, 1992.

Sinkevičius, V. Seimo narių rinkimai: kai kurie teoriniai ir praktiniai rinkimu teisès aspektai. Jurisprudencija. 2008, 9(111).

Statement from the General Command of Egypt's Armed Forces [interaktyvus]. 3rd July 2013 [žiūrèta 2013-07-10]. <http://soupsoup.net/2013/07/04/statement-from-the-general-commandof-egypts-armed-forces/>.

Sturm, R. Daspolitische System Grosbritanniens. Ismayr, W. (Hrsg.) Die politischen Systeme Westeuropas, 4., ak- 
tualisierte und uberarbeitete Auflage. Wiesbaden, 2009.

The Constitution of the Arab Republic of Egypt - approved on 30 Nov 2012 [interaktyvus]. 30 November 2012 [žiūrèta 2013-07-10]. <http://www. constitutionnet.org/vl/item/new-constitution-arab-republic-egypt-approved-30-nov-2012>.

The Constitutional Declaration on 8 July 2013 [interaktyvus]. 8 July 2013 [žiūrèta 2013-07-10]. <http://www.constitutionnet.org/vl/item/egypt-constitutional-declaration-8-july-2013>.
Vainiute, M. Vokietijos Federacinès Respublikos Prezidento konstitucinis statusas. Prezidentas valstybinés valdžios instituciju sistemoje. Vilnius: MES, 2011.

Vaitiekienè, E.; Mesonis, G. Lyginamoji konstitucine teise. Vilnius: Justitia. 2011.

Vedel, G. Manuelélémentaire de Droit Constitutionnel. Recueil Sirey, 1949.

Žalimas, D. Lietuvos Respublikos užsienio politikos konstituciniai pagrindai. Lietuvos konstitucine teisé: vadovèlis: liber amicorum Juozui Žiliui. Vilnius: Mykolo Romerio universitetas, 2012.

\title{
CONSTITUTIONAL FUNDAMENTALS OF ACTIONS BY EGYPTIAN DEFENSE MINISTER ON JULY 3RD, 2013: COMPARATIVE ANALYSIS
}

\author{
Kristina Kenstavičienè
}

Mykolas Romeris University, Lithuania

Summary. Actions by Egyptian Defense Minister on July 3rd, 2013 raised a question on what sort of means secure democratic military control and whether a democratic state can limit and control the use of force in a democratic manner. For this reason, in comparison with constitutional provisions of other states that embody different forms of government, this article analyses the constitutional status of a state leader as a head of military forces that was infixed in the Constitution of the Arab Republic of Egypt of December 26th, 2012, and also what constitutional fundamentals existed for Egyptian Defense Minister to perform actions on July 3rd, 2013, or to prevent these actions from materializing.

The process that at the moment is in action in Egypt is an important test for democracy, which up until now the state has been having trouble to pass. When looking at the state government system provisioned by the Constitution of the Arab Republic of Egypt of December 26th, 2012, it becomes clear that the Constitution lacks more visible balance of power, which in turn creates the lack of democracy. Various military councils and military forces are equal to other three state powers (legislative, executive and judicial), but in a democratic country, military institutions of the state cannot be ascribed to state government institutions and furthermore have a priority over them. On the contrary, military state institutions must be liable to civil state institutions and must be controlled by them, and their decisions must be based on decisions by civil state institutions. 
Actions by Egyptian Defense Minister on July 3rd, 2013 were performed in breach of constitutional provisions that were set by the nation to live in accordance with, and this Constitution was validated in a referendum. According to the Constitution, Defense Minister is not the Protector of the Constitution; furthermore, no right is provisioned for him to terminate the validity of the Constitution. The Egyptian Constitution does not provide the Defense Minister with a right to dismiss the President of the Republic from the office and to appoint a constitutional jurisdiction judge to a temporary President office. What is more, it was possible to solve a political crisis apparent in a country and to avoid breaches of the Constitution by implementing other constitutional means (noconfidence, impeachment or election institutions).

Keywords: state leader as a head of military forces, defense minister, military leader, Constitution.

Kristina Kenstavičienė, Mykolo Romerio universiteto Teisès fakulteto Konstitucinès ir administracinès teisès instituto lektorè. Mokslinių tyrimų kryptys: konstitucinè teisė, parlamentinè teisé, valstybès gynybos konstituciniai pagrindai.

Kristina Kenstavičienė, Mykolas Romeris University, Faculty of Law, Institute of Constitutional and Administrative Law, lector. Research interests: constitutional law, parliamentary law, constitutional fundamentals of state defense. 